\title{
Different Farm Production System Practiced in Simdega District, Jharkhand, India
}

\author{
Neera Sabita Jojo and Jai Prakash* \\ Department of Ag. Econ., RAC, BAU, Kanke, Ranchi, Jharkhand, India \\ *Corresponding author
}

\begin{tabular}{|l|}
\hline Key w or d s \\
Farm production \\
system, Grains
\end{tabular}

\section{A B S T R A C T}

Farm diversification is advocated for reaping the gains of complementary relationship or equating substitution and price ratio for completing products. Farm diversification may also be used as a risk precaution and stabilize farm income. Diversification of crop farming along with livestock enterprises can play more significant role in increasing income and employment particularly on marginal and landless labourers and in meeting nutritional requirements. Besides land owing households, livestock also reared by a large number of other households, most of which belongs to poorer section of the society. Because of this, livestock wealth in India is more egalitarian compared to land and hence it is found to promote equity and livelihood security. In view of the importance of mixed farming system, it is important for decision making about the optimum level of livestock adjustment with the crop farming in total enterprises mix. It is essential that the farmers are guided about the profitable level of crop and livestock enterprises so as to maximize their income. Examination of the mixed production system in the study area reveled that crop plus milch animals production system was the most important systems adopted by the 36 percent of the sample households. Crop plus goat production system was the next most prevalent system adopted by 44 households out of the 200 households ( 22 percent) other systems prevalent in the study area were crop enterprise alone, ( 9 percent), crop plus pigs (17percent) and crop plus livestock (16 percent).

\section{Introduction}

Agriculture is one of the most important sectors of the Indian economy. It continues to be the back bone of our national economy contributing about 12 percent of the Gross domestic product (G.D.P.) and accounting for about two third of the employment in the country. Nearly $58 \%$ percent share in employment from agriculture sector. Agriculture provides not only food for farm and non-farm family and raw materials for industries but also generates employment to a very large proportion of the population. Crop enterprises became a major powerful instrument for a comprehensive socio economic transformation of the country including importance in the quality of life of every individual. The entire population in a country is socially divided between villages (rural) and towns (urban). Largely the rural population engaged in agricultural activities and the urban population involved in manufacturing activities. As long as adequate 
land and labour was available, agricultural production would go unhindered. Also an increase in agriculture surplus meant that there were more raw materials available for the manufacturing sector. Thus, it is the agriculture sector which provides food for the entire populace of a country. But food is not sufficient for whole population. So, diversification in agriculture needs to fulfill the gap between availability and requirement of food through improvement in income and employment of people of the country.

Farm diversification is advocated for reaping the gains of complimentary relationships or equating substitution and price for competitive products. Farm diversification may also be used as a risk precaution and stabilizes farm income. Diversification of crop farming along with animal husbandry enterprise can play more significant role in increasing income, employment on marginal farmers, because the crop cultivation alone in India is subject to a high degree of risk and uncertainty and provides only seasonal, irregular and uncertain incomes to the farmers. It was observed that if dairying was incorporated in the optimal plans along with crop production, a regular flow of income could be generated throughout the year Dairying, being a self income generating enterprise, reduces the irregularity and uncertainty in farm business (Dhawan and Johl). Though the Indian farmers have long experiences of rearing the milch animals with crop enterprises, but recent changes in the components of livestock and crop production pose a difficult problem in decision making to make diversification of crop cultivation and incorporate livestock enterprise optimally with crop farming of the tradition bounds farmers, who wish to maximize their farm profit within the framework of scarce resources and other constraints. Livestock sector plays an important role in generating income and employment augmenting income of the marginal farmers and landless labourers and in meeting nutritional requirement. Farmers, in general, in India follow mixed crop and livestock farming system because of strong linkage between these two. Though the dairy enterprise reduced the farm returns to some extent but it was advised to be incorporated at least at small scale to provide regular and stable income on the farm (JohI and Kahlon). Dairying is being a self-income generating enterprise, reduce the short term credit requirement by supplying regular income to the farmers (Singh et al., 1998)

Radhakrishnan and Sivanandhan (1975) observed that optimum cropping pattern and livestock combination generated about 44 per cent additional income with the available fixed farm resources of land, labour, irrigation water etc. in Coimbatore Taluk of Tamil Nadu state.

The geographical area of Jharkhand is about 80 lakh hectare of which 18 lakh hectare is net sown area $(23 \%)$ and area sown more than once is about 2.60 lakh hectare (14 per cent of net sown area) in the state. Of the total area, the forest is 30 percent and 41 percent under barren and uncultivated land. About 10 per cent of the cropped area is irrigated. Animal husbandry is an integral part of the diversified agriculture system. The animal husbandry sector plays a crucial role in the rural economy by providing gainful employment particularly to small, marginal farmers and agricultural labourers. It provides gainful employment and source of income among landless labour and additional income to families through employment of women. In the agrarian economy of Jharkhand, livestock also plays an important role in contribution to income, employment and women empowerment. According to the $17^{\text {th }}$ livestock census 2003, the livestock in the state is about 76 lakh cattle, 13 lakh buffaloes, 6 lakh sheep, 50 lakh goats and 11 lakhs pigs support the agricultural base of the State. The average size of agricultural holding is less than one hectare 
and more than 88 percent farmers, beings marginal and small categories. (Department of Animal Husbandry, Jharkhand).

The cropping intensity as stated above is 110 percent at state level, while in some districts it is less than 100. This situation leads to mono cropping farming system and force rural people to migrate from the villages to other part of the country. The average productivity of land is also very low in comparison to other parts of the country. However, the state is having large population of livestock but unfortunately lactating animal is very poor in genetic character and poor feeding and breeding management result poor production of local cow (nearly $1 \mathrm{~kg}$ per day). Keeping the stock of livestock population, in consideration, it is urgently needed to combine livestock with crop farming for sustainable production in the State (SAMETI, Jharkhand).

Jharkhand State is mainly divided into three agro-climatic zones (1) Agro-climatic ZoneIV, (2) Agro-climatic Zone-V and (3) Agroclimatic Zone-VI. The production system which are generally found in this state are, Local cow + crops, Goat + crops, Pigs + crops, livestock + crops, Buffalo +crop. (Report of NATP, 2004, Department of Ag. Econ. B.A.U. Kanke).

The study conducted here will be a source of useful information on scarce and surplus resources which can be further exploited to improve employment and efficient use of farm resource for the development of both crop and livestock enterprises. Further, the information generated on requirement, utilization, surplus and potentiality of different resource would be useful to the policymakers, planners, administrators, scientist and all those who are interested in the development of the rural sector. Keeping these considerations in view, the present study was designed with the following specific objectives.

\section{Objectives}

To identify various mixed farm production system practiced on sample farms.

To carry out economic analysis of various mixed production systems.

\section{Materials and Methods}

Tabular analysis of primary data collected from the sample of 200 households, which were selected randomly with the help of probability proportional method. The informations were collected carefully by interviewing to the selected households in the agricultural year 2016-17 and apprise the status of various mixed livestock and crop enterprises, economic aspects of each of the mixed system followed on the three farm categories, contribution of livestock to total farm income in each production system, capital, utilization of livestock and human and bullock labour employment on various livestock and crop production practicising mixed farming system.

To obtain elasticities of production with respect to individual input, a production function analysis is used. These elasticities are then used to obtain the value of share of each factor in the total value of production with the assumption that factor shares are proportional to the factor production elasticities. These elasticities are directly obtained by the estimated coefficient of a Cobb-Douglas production function. Thus, in the present analysis Cobb- Douglas production function was estimated based on fact that it gives relatively better fit to farm input- output data. Also, it is easy to estimate and results can easily be interpreted. A separate CobbDouglas production function was thus estimated for total farm business income for each of the five combined production systems followed on the three farm sizes. Due to lack 
of required number of observations on production systems followed separately on the three size categories, a production system followed on all the three size classes was pooled. Thus, a comparison of resource use efficiency was held between different productions systems followed on the three size categories.

Owing to the problem of multi-collinearity, all the cash inputs used by farmers of a production system in the three size groups could not be included in the production equation. Inclusion of all these cash inputs in production function resulted in large sampling variance of estimates of coefficients, thus making them non-significant. It was thus necessary to either exclude some of these variables from the production equation or pool them together. The latter option was preferred and all these cash inputs which included seeds, fertilizers, manures, irrigation, plant protection and other cash expenses were grouped together to form the aggregate variable referred here and onwards as capital input. This was easily done because these inputs (purchased ones) were measured in rupee term and were very easily pooled together. This approach reduced the number of explanatory variables and possible multi-collinearity among them. The final run equation for each production system thus, contained only four variables, namely cropped area (ha) human labour (mandays) bullock labour (pair days) and capital inputs (Rs.).The results of the estimates of regression coefficients of these variables along with other related static for each of the production systems are presented.

As estimated equations are based on CobbDouglas type of production function (which is linear in logarithm), the regression coefficients of these equations denote the elasticity of production for the input concerned. Each coefficient indicates the percentage increased in gross returns associated with one percent increase in the quantity of corresponding resource, holding other resources in the equations constant at their mean level.

\section{Results and Discussion}

\section{Characteristic of land holding on different size of farms}

It is revealed from the table 1 that there is difference in proportion of areas under upland, medium land and lowland in total agricultural holdings per farm in various size groups of farms under investigation. The proportions of upland to total land were about 55.91 percent, 44.60 percent and 52.85 percent on marginal, small and medium size of farms, respectively.

The proportions of medium land to total land were about 22.58 percent, 32.01 percent and 27.85 percent on marginal, small and medium size of farms respectively. The contribution of lowland to total land was about 21.51 percent, 23.39 percent and 19.30 percent on marginal, small and medium size of farms, respectively. Altogether the average proportion of areas under upland, medium land and lowland to total land were 50.37 percent, 28.62 percent and 21.01 percent respectively.

It was found that proportion of upland to total agricultural land was higher on marginal farms as compared to small and medium farms. But in case of medium low land, it was quite higher on small farm as against marginal and medium size of farms. The proportion of low land is also higher in small size of farm than that of marginal and medium categories of farms.

It was observed that there was large variation in proportion of upland, medium land and low land to total agricultural land per farm on different size group of farms. It was mainly due to undulated topography of land in the area of investigation. 
Table.1 Average size of agricultural holding in different size of farm

\begin{tabular}{|l|c|c|c|c|}
\hline \multicolumn{1}{|c|}{ Type of land } & Marginal & Small & Medium & A verage \\
\hline Upland & 0.52 & 1.24 & 2.41 & 1.39 \\
& $(55.91)$ & $(44.60)$ & $(52.85)$ & $(50.37)$ \\
\hline Medium land & 0.21 & 0.89 & 1.27 & 1.27 \\
& $(22.58)$ & $(32.01)$ & $(27.85)$ & $(28.62)$ \\
\hline Low land & 0.20 & 0.65 & 0.88 & 0.88 \\
& $(21.51)$ & $(23.39)$ & $(19.30)$ & $(21.01)$ \\
\hline Grand total & 0.93 & 2.78 & 4.56 & 2.76 \\
& $(100)$ & $(100)$ & $(100)$ & $(100)$ \\
\hline
\end{tabular}

Table.2 Different type of production systems identified on the sample farms

\begin{tabular}{|l|c|c|c|c|}
\hline Production Systems & Marginal & Small & Medium & Total \\
\hline Crop & 10 & 08 & - & 18 \\
\hline Milch animals + Crop & 29 & 29 & 14 & 72 \\
\hline Goatry + Crop & 21 & 18 & 05 & 44 \\
\hline Piggry + Crop & 18 & 12 & 04 & 34 \\
\hline Livestock + Crop & 13 & 11 & 08 & 32 \\
\hline Total & 91 & 78 & 31 & 200 \\
\hline
\end{tabular}

Table.3 Regression coefficient along with their standard errors and coefficient of multiple determination of different production systems

\begin{tabular}{|c|c|c|c|c|c|c|c|c|}
\hline $\begin{array}{l}\text { Production } \\
\text { system }\end{array}$ & $\begin{array}{c}\text { No. of } \\
\text { observation }\end{array}$ & $\begin{array}{l}\text { Intercept } \\
\text { term ' } a \text { ' }\end{array}$ & $\begin{array}{c}\text { Area } \\
\text { (ha) } \\
\mathbf{X}_{1}\end{array}$ & $\begin{array}{l}\text { Human } \\
\text { labour } \\
\text { (days) } X_{2}\end{array}$ & $\begin{array}{c}\text { Bullock } \\
\text { labour } \\
\text { (days) } \\
\mathbf{X}_{3}\end{array}$ & $\begin{array}{l}\text { Capital } \\
\text { inputs } \\
\mathbf{X}_{4}\end{array}$ & $\mathbf{R}^{2}$ & $\sum_{\mathrm{i}}^{\mathrm{e}}$ \\
\hline $\begin{array}{l}\text { Crop } \\
\text { enterprises }\end{array}$ & 18 & 7.8630 & $\begin{array}{l}0.6128 * \\
(0.2230)\end{array}$ & $\begin{array}{c}0.2096 * * \\
(0.0982)\end{array}$ & $\begin{array}{c}0.0658 * * \\
(0.0220)\end{array}$ & $\begin{array}{c}0.2038 * * * \\
(0.0300)\end{array}$ & 0.92 & 1.09 \\
\hline $\begin{array}{l}\text { Crop } \\
+ \text { dairy }\end{array}$ & 72 & 3.5612 & $\begin{array}{l}0.5519 * \\
(0.2735)\end{array}$ & $\begin{array}{c}0.2819 * * * \\
0.1036\end{array}$ & $\begin{array}{c}0.0833 \\
(0.1036)\end{array}$ & $\begin{array}{l}0.1809 * \\
(0.1022)\end{array}$ & 0.87 & 1.11 \\
\hline $\begin{array}{l}\text { Crop } \\
+ \text { goat }\end{array}$ & 44 & 8.9206 & $\begin{array}{l}0.5069 * \\
(0.2218)\end{array}$ & $\begin{array}{c}0.2588 \\
(0.1826)\end{array}$ & $\begin{array}{c}0.0769 * * \\
(0.0259)\end{array}$ & $\begin{array}{c}0.1668 * * \\
(0.0668)\end{array}$ & 0.88 & 1.01 \\
\hline $\begin{array}{l}\text { Crop + } \\
\text { piggry }\end{array}$ & 34 & 4.2436 & $\begin{array}{l}0.5209 * \\
(0.3152)\end{array}$ & $\begin{array}{l}0.2060 * \\
(0.0826)\end{array}$ & $\begin{array}{c}0.0626 \\
(0.0369)\end{array}$ & $\begin{array}{c}0.2760 * * * \\
(0.0826)\end{array}$ & 0.96 & 1.06 \\
\hline $\begin{array}{l}\text { Crop + } \\
\text { livestock }\end{array}$ & 32 & 6.2960 & $\begin{array}{c}0.5928 * * \\
(0.2606)\end{array}$ & $\begin{array}{l}0.1962 * * \\
(0.0809)\end{array}$ & $\begin{array}{c}0.0650 \\
(0.0961)\end{array}$ & $\begin{array}{c}0.1526 * * * \\
(0.0366)\end{array}$ & 0.93 & 1.02 \\
\hline
\end{tabular}

Figure in parenthesis indicate standard error of the estimated coefficients.

***Significant at the 1 percent level of significance.

**Significant at the 5 percent level of significance.

*Significant at the 10 percent level of significance. 
Types of production system identified on the sample farms

The different type of mixed farm production systems identified on the three categories of households is presented table 2. As can be seen from the table, five types of production systems are seemed to exist on sample households. Crop production is the base of all the production system. The number of farm households which were engaged in only crop production on marginal and small farms were 10 and 08 , respectively. They had no any type of livestock enterprises. On medium farm households not a single family was found to be engaged in only crop production system.

The number of households which were practicing Crop production + milch animals production system on marginal, small and medium size of farms were 29,29 and 14 respectively. The total number of farm households in all the three categories engaged in this farming system were 72 .

In Crop + goatry production systems practiced by marginal, small and medium farm households number were 21, 18 and 05 , respectively. The total number of farm households that practiced this farming system was 44 .

The number of farm household were engaged in crop + piggry production systems on marginal farm, small farm and medium farm were 18,12and 04 respectively. Thus the total number of farm household who were engaged in this system was 34 .

In Crop + livestock production systems was practiced by marginal, small and medium farm households who's number were 13, 11 and 08, respectively. The total number of farm households which practiced this farming system was 32.From the table it is seen that crop plus milch animals has the most number of households (72) on the three categories. The next important production system practicised by 44 households is identified as crop + goatry system.

Production function analysis and resource use efficiency under different production systems

Gross agriculture output is a function of various input factors such as land, human labour, bullock labour, manures. Fertilizers, irrigation, plant protection measure etc. The variation in the level of these inputs directly affects the gross agriculture output on farmers of different categories. At individual farm level, each farm operator of each production system must decide how to combine different quantities of various resources most profitable. Ideally, one should use each resource up to the point where the marginal cost is equal to the marginal return in the range of output curve where the marginal return is declining. By estimating elasticities and marginal value productivities of input resources, one can then estimate the optimal uses of the farm resources and determine the extent of adjustment in the use of resources in each production system on respective farm size to attain the economic optimum.

The size of the coefficients of multiple determination $\left(\mathrm{R}^{2}\right)$ shows the degree of success in estimating the production relationship and selection of the explanatory variables in all the equations for the farm business incomes or farm returns, which are explained by the included explanatory variables. It can be seen from the table that high $\mathrm{R}^{2}$ values were obtained in each case of equation for the different systems of mixed production. These were estimated as 92 percent, 87 percent, 88 percent, 96 percent and 93 percent for the respective production 
system of crop production, crop + dairy, crop + goat, crop + pig and crop + livestock, respectively. These estimates indicate that major portion of the variations in total mixed farm production were captured by the selected variables in the estimated equations. It also justified the approach of aggregating the cost input variables into capital variable, without much loss in explanatory power of the either equations. It is so because the degree of explanatory power of an estimated equation is believed to be higher with large number of explanatory variables in an equation. Thus, a good success was obtained in estimating the equation with only four explanatory variables included in each equation for the five mixed production systems identified on the, three categories of the farms in the area studied.

It can be seen from the table 3 that the elasticities of production of all the farm inputs engaged in the production function are positive indicating that neither of the resources was used upto a point, that additional use of these resources will tend to decrease the total return. The production elasticities for various farm inputs in all the five systems of mixed production varied from 0.0626 (for bullock labour) to 0.6128 (for land area) in crop entreprises. Thus, we see that in all the three cases, the coefficients of elasticity of production of all inputs were less than unity, indicating that the law of diminishing return was operative with respect to each input in the production of crop plus livestock on all the three size classes of farm. It can further be seen that the sums of production elasticities in each equation are nearly one indicating that the farmers of each size class were subject to operation under constant returns to scale in all the production systems adopted by them.

A close examination of the existing operational holding of the farm selected indicated that major portion of land on all the three categories was in form of upland which constituted 56 percent on marginal farms, 45 percent on small and 53 percent on medium sized farms. The marginal and small farms who were about 85 percent of the total farms selected, owned only 45 percent of the cultivated area. The medium farms being only 15 percent occupied 55 percent of the cultivated area. Examination of the mixed production system indicated that crop plus milch animals production system was the most important systems adopted by the 36 percent of the sample households. Crop plus goat production system was the next most prevalent system adopted by 44 households out of the 200 households (22 percent) other systems prevalent in the study area were crop enterprise alone, (9 percent), crop plus pigs (17percent) and crop plus livestock (16 percent). Whereas majority of small and medium farms adopted crop plus milch animal production systems, crop plus goat and crop plus pigs were practicized mostly by marginal farmers. The evaluation of economic profitability of alternative production systems at the farmers existing production plan indicating that input-output ratio were increasing with increase in the size of the holdings in each production systems. This showed the increase in profitability associated with size of farms, irrespective of the production system followed on either size class. This necessarily indicated a better resource management on higher land holdings and confirmed the prevalence of economics of scale on larger holding sizes.

Finally, the overall conclusion that emerged from this study is that reallocation of the fixed farm resources in mixed farming has a positive effect on the income and employment on all the synthetic farm situations adopting either mixed production system of crop plus dairy, crop plus goat, crop plus pigs and crop plus livestock constituting more than one type of animals. Further, the adoption of improved 
technology coupled with adequate credit facility and inclusion of livestock dynamises the entire gamut of income potential and offers the single best measure to solve the chronic problem of under employment of family labour on marginal and small farms. Dairying, goatry and piggry, being a selfincome generating enterprise, reduces the short term credit requirements by supplying regular income to the farmers, and these practices should be encouraged on these farms.

\section{References}

Dhawan, K.C. and Johl, S.S. (1967). Comparative profitability of dairy enterprises in relation to crop cultivation on sub urban farms in Punjab - A case study. Indian J. Agril. Econ., 22(1): 81-97.

Johl, S.S. and Kahlon, A.S. (1963). Economics of cropping pattern- an analytical case study. Indian J. Agril., Econ., 18(1):132-142.

Johl, S.S. and Kahlon, A.S. (1967). Application of programming technique to Indian farming conditions. Punjab Agricultural University Press, Ludhiana, p.62-82.

Johl, S.S., Kahlon, A.S. and Dhawan, K.C. (1965). Economics of dairy buffaloes in the sub-urban areas of Punjab - A case study. J. Res. Punjab Agricultural University, Ludiana, 2(3):231-37.

Radhakrishnan, S.A. and Sivanandhan (1975). Dairying as a subsidiary enterprise in farm-A micro level analysis. Indian J. Agril. Econ., 30(3):159.

Singh, N.K., Rajvir Singh and R.P. Singh (1998). Impact of crop diversification on income employment and credit needs of marginal farms. The Bihar journal of Agricultural Marketing, 6(2): 160-170.

\section{How to cite this article:}

Neera Sabita Jojo and Jai Prakash. 2018. Different Farm Production System Practiced in Simdega District, Jharkhand, India. Int.J.Curr.Microbiol.App.Sci. 7(04): 2121-2128. doi: https://doi.org/10.20546/ijcmas.2018.704.242 